\title{
Plant community responses to changes in management
}

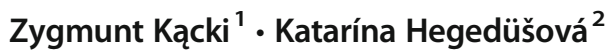

Published online: 25 March 2019

(C) Plant Science and Biodiversity Centre, Slovak Academy of Sciences 2019

\section{Introduction}

The development of settlements in the postglacial period in Europe has contributed to the expansion of numerous plant communities strongly dependent on human activity. Over the past century, changes caused by human activity have shaped contemporary vegetation on both a local and global scale, due to changes in land use methods and climate. With the rise in greenhouse gas emissions and resulting global climate change, the intensity and scope of human impact on the natural environment and the organisms occurring within has touched almost all global ecosystems, from the Arctic to Antarctica (Turner et al. 2005; Robinson et al. 2018; Wegrzyn et al. 2018). These changes portend a bleak future for terrestrial and aquatic ecosystems. Considering their particular sensitivity to changes in temperature, ecosystems will undergo transformations that threaten their stability and biodiversity (Nolan et al. 2018). Ecological extinction and declining ecosystem biodiversity, particularly of specialist species, has been reported for many years (IUCN Reports). The human impact on the environment is exhibited primarily in the extinction of key native dominant species, resulting in significant changes in primary productivity, along with many other ecological phenomena such as changes in species ranges or invasion of alien species (Hooper et al. 2012; Allen et al. 2015; Mang et al. 2018). Another important factor responsible for changes in plant communities is land use change and improvements in farming systems, which have a strong influence on vegetation, especially on a local scale. Economic transformations in recent decades are the

Zygmunt Kącki

zygmunt.kacki@uwr.edu.pl

Katarína Hegedüšová

katarina.hegedusova@savba.sk

1 Botanical Garden, Department of Vegetation Ecology, University of Wroclaw, ul. Sienkiewicza 23, 50-335 Wrocław, Poland

2 Institute of Botany, Department of Geobotany, Plant Science and Biodiversity Center, Slovak Academy of Sciences, Dúbravská cesta 9, 84523 Bratislava, Slovak Republic catalyst for significant changes in the use of natural, semi-natural and anthropogenic plant communities in many parts of the world, largely due to human population growth and increasing demand for food and raw materials. One of the most endangered plant communities are grasslands and agricultural vegetation. In Europe, these ecosystems have been associated with agriculture since the Neolithic, and they are currently exposed to strong intensification of agricultural treatments (Burrichter et al. 1993; Isselstein et al. 2005). Understanding the impact of management on the diversity and stability of vegetation is a key challenge for nature conservation. It was also the inspiration for the Special Issue on "Plant community responses to changes in management", which was initiated by the Managing Editor of Biologia together with the Chairman of the Organizing Committee of the 27th Congress of the European Vegetation Survey (IAVS Working Group, http://euroveg.org/) in Wrockaw, Poland. In the current Special Issue of Biologia, we present eight research articles summarising plant community responses to changes in management. The articles also highlight some general problems of monitoring systems for improving nature protection.

\section{Main problems discussed in the presented studies}

One of the studies provides insight into the regeneration management problems of the rare, charismatic dragon's blood tree Dracaena cinnabari on Yemen's Socotra Island. This tree is an endangered species with limited distribution, which is likely the result of two factors: changes in environmental conditions and overgrazing by goats (Nadezhdina et al. 2019). Based on field experiments, the authors suggest that grazing has a substantial impact on the natural regeneration of the dragon's blood tree, and they develop a conservation strategy for restoration of this plant in indigenous habitats.

Much attention has recently been focused on agricultural field diversity and the ecosystem services they provide. Arable fields belong to habitats whose vegetation is seriously threatened by the intensification of agriculture (Meyer et al. 2013). Modern 
agriculture has greatly simplified crop diversity and crop rotation; this in turn limits the occurrence of many ancient weed species (archaeophytes), which have declined dramatically in Europe (Anioł-Kwiatkowska and Kacki 2006; Meyer et al. 2010; Knox et al. 2011). On the other hand, a considerable increase in alien species in agricultural crop communities has been observed (Lososová and Simonová 2008). The extinction of segetal species is also strengthened by increased crop yields and crop plant density (Storkey et al. 2012). Nowak et al. (2018) demonstrated on experimental plots that crop density has an important role in limiting the growth of species accompanying crops, and this applies to both ancient weeds and ruderal species (including neophytes). This result is important for weed control planning and arable plant conservation. However, in Europe, semi-natural vegetation plays the most important role in maintaining biodiversity and providing high-value ecosystem services, where extensive management helps to sustain high biodiversity in agricultural landscapes (García-Feced et al. 2015). According to Navrátilová et al. (2019), areas of semi-natural grasslands on organic soils have decreased in comparison to other plant communities as a result of land cover changes in the Czech Republic over the last 150 years. Generally, two processes are observed in land use changes in Europe, namely increasing agricultural production in some areas, and the abandonment of traditional practices, both of which have a large influence on plant communities and biodiversity (Halada et al. 2011; Timmermann et al. 2015). Abandonment causes changes in species composition and soil properties in grasslands (Swacha et al. 2018), and promotes invasion by species with special competitive adaptations (Prévosto et al. 2011). In the current Special Issue, Pätsch et al. (2019) provide insight into the expansion of Elytrigia repens on Baltic low-growing salt meadows due to the abandonment of grazing. Salt meadows are considered endangered vegetation in the EU (Janssen et al. 2016); thus, to protect these grasslands, a monitoring approach has been proposed. Heavily destroyed landscape in post-industrial areas is dominated by anthropogenic vegetation. This interesting type of habitat can be studied to show plant community responses to succession depending on habitat quality and restoration practice (Prach 2003). Newly made coal mine spoil heaps are places for spontaneously developing vegetation on poor initial soils characterised by different soil fractions and chemical properties. The relationship between physicochemical properties of heaps and vegetation is discussed here by KompałaBaba et al. (2019). The authors found that different soil fractions influenced the development of vegetation, with fine-particle-size soil fractions having the strongest influence on vegetation diversity. These results have important implications for vegetation management and land restoration in industrial coal mining areas.

Different problems are connected with forests, which are usually considered natural vegetation. Forest management has influenced most of the woodlands in Europe, and the natural forest cycle has been altered by human interference. At the same time, deadwood abundance has been reduced considerably, despite its significant role in maintaining biodiversity (Harmon et al. 1986; Bobiec et al. 2005). The abundance of standing deadwood and logs in different stages of decay is dependent on many factors. Natural and anthropogenic factors that influence the diversity of bryophytes and lichens found on deadwood and other organic substrates are discussed in the Special Issue (Staniaszek-Kik et al. 2019; Vondrák and Kubásek 2019). Standing wood in the Giant Mountains (Czech Republic) is an important habitat colonised mostly by lichens. Species diversity in this group is strongly linked to vegetation type and the occurrence of snags, the distribution of which is related to forest management introduced after dieback of spruce caused by pollution in the 1980s (Staniaszek-Kik et al. 2019). A relationship between vegetation type and lichen distribution and diversity was also found by Vondrák and Kubásek (2019). Humanmade forests, especially plantations of Norway spruce Picea abies, are less favourable habitats for lichens than natural forests. On the other hand, air pollution and climate change likely promote some groups of lichens, whereas others decline rapidly. In the Šumava Mountains, notable winners are epixylic nitrophilous species, whose population tends to increase.

Plant communities respond to changes in management in many different ways. The assessment of consequences for vegetation diversity is essential to protecting nature and biodiversity conservation. This is especially important for poorly recognised vegetation such as the class Rhamno-Prunetea, which can be distinguished based on problematic species of the genus Rubus (Haveman and de Ronde 2019). Marginal fringe vegetation plays an important role in maintaining biodiversity in agricultural landscapes. Unfortunately, due to changes in land use, bramble scrubs have been altered significantly, although there is still little known about the dynamics and diversity of this vegetation (Huwer and Wittig 2012).

Acknowledgements We would like to thank the authors who contributed to this Special Issue of Biologia and sent the results of their studies. We are also grateful to our guest editors, editors Anna Bérešová-Guttová, Ladislav Mucina, Milan Valachovič, and reviewers for their detailed insight into manuscripts and helpful comments. Our special thanks is given to the Springer team for their work on the papers before publication.

Katarína Hegedüšová was funded by VEGA grant 2/0040/17 during preparation of the Special Issue.

\section{References}

Allen CD, Breshears DD, McDowell NG (2015) On underestimation of global vulnerability to tree mortality and forest die-off from hotter drought in the Anthropocene. Ecosphere 6:129. https://doi.org/10. 1890/ES15-00203.1

Anioł-Kwiatkowska J, Kącki Z (2006) Species diversity of segetal plant communities in the early Neolithic settlement area of the Śl ża Landscape Park. Acta Soc Bot Pol 75(3):257-262

Bobiec A, Gutowski JM, Zub K, Pawlaczyk P, Laudenslayer WF (2005) The afterlife of a tree. WWF Poland, Warszawa 
Burrichter E, Hüppe J, Pott R (1993) Agrarwirtschaftlich bedingte Vegetationsanreicherung und -verarmung in historischer Zeit. Phytocoenologia 23:427-447. https://doi.org/10.1127/phyto/23/ $1993 / 427$

García-Feced C, Weissteiner CJ, Baraldi A et al (2015) Semi-natural vegetation in agricultural land: European map and links to ecosystem service supply. Agron Sustain Dev 35(1):273-283. https://doi. org/10.1007/s13593-014-0238-1

Halada L, Evans D, Romão C, Petersen J (2011) Which habitats of European importance depend on agricultural practices? Biodivers Conserv 20:2365-2378. https://doi.org/10.1007/s10531-011-9989-

Harmon ME, Franklin FJ, Swanson P et al (1986) Ecology of coarse woody debris in temperate ecosystems. In: MacFadyen A, Ford ED (eds) Advances in ecological research, vol 15. Academic Press, Orlando, pp 133-276

Haveman R, de Ronde I (2019) Vegetation classification as a mirror of evolution? Thoughts on the syntaxonomy and management of bramble scrubs of the Prunetalia (Rhamno-Prunetea). Biologia 74(4).https://doi.org/10.2478/s11756-019-00199-x

Hooper DU, Adair EC, Cardinale BJ et al (2012) A global synthesis reveals biodiversity loss as a major driver of ecosystem change. Nature. https://doi.org/10.1038/nature11118

Huwer A, Wittig R (2012) Changes in the species composition of hedgerows in the Westphalian Basin over a thirty-five-year period. Tuexenia 32:31-53

Isselstein J, Jeangros B, Pavlu V (2005) Agronomic aspects of biodiversity targeted management of temperate grasslands in Europe - a review. Agron Res 3(2):139-151

Janssen JAM, Rodwell JS, García Criado M et al (2016) European red list of habitats. Part 2. Terrestrial and freshwater habitats. European Union, Luxembourg

Knox OGG, Leake AR, Walker RL, Edwards AC, Watson CA (2011) Revisiting the multiple benefits of historical crop rotations within contemporary UK agricultural systems. J Sustain Agric 35:163-179

Kompała-Baba A, Bierza W, Błońska A, Sierka E, Magurno F, Chmura D, Besenyei L, Radosz Ł, Woźniak G (2019) Vegetation diversity on coal mine spoil heaps - how important is the texture of the soil substrate? Biologia. https://doi.org/10.2478/s11756-019-00218-x

Lososová Z, Simonová D (2008) Changes during the 20th century in species composition of synanthropic vegetation in Moravia (Czech Republic). Preslia 80:291-305

Mang T, Essl F, Moser D, Dullinger S (2018) Climate warming drives invasion history of Ambrosia artemisiifolia in Central Europe. Preslia 90:59-81. https://doi.org/10.23855/preslia.2018.059

Meyer S, Wesche K, Krause B, Leuschner C (2013) Dramatic losses of specialist arable plants in Central Germany since the $1950 \mathrm{~s} / 60 \mathrm{~s}-\mathrm{a}$ cross-regional analysis. Divers Distrib 19(9):1175-1187. https://doi. org/10.1111/ddi.12102

Meyer S, Wesche K, Metzner J, van Elsen T, Leuschner C (2010) Are current agri-environment schemes suitable for long-term conservation of arable plants? - a short review of different conservation strategies from Germany and brief remarks on the new project ' 100 fields for diversity'. Asp Appl Biol 100:287-294

Nadezhdina N, Al-Okaishi A, Maděra P (2019) Long-term in situ sap flow monitoring in a mature Dracaena cinnabari tree on Socotra. Biologia. https://doi.org/10.2478/s11756-018-00185-9

Navrátilová J, Havlíček M, Navrátil J, Frazier RJ (2019) Land cover changes on temperate organic substrates over last 150 years: evidence from the Czech Republic. Biologia. https://doi.org/10.2478/ s11756-018-00183-x
Nolan C, Overpeck JT, Allen JRM et al (2018) Past and future global transformation of terrestrial ecosystems under climate change. Science 361(6405):920-923. https://doi.org/10.1126/science. aan5360

Nowak S, Waindzoch K, Świerszcz S, Niemczyk M, Spałek K, Nowak A (2018) Crop density rather than ruderal plants explains the response of ancient segetal weeds. Biologia. https://doi.org/10.2478/s11756018-00178-8

Pätsch R, Bruchmann I, Schellenberg J, Meisert J, Bergmeier E (2019) Elytrigia repens co-occurs with glycophytes rather than 23 characteristic halophytes in low-growing salt meadows on the southern Baltic Sea coast. Biologia. https://doi.org/10.2478/s11756-01900195-1

Prach K (2003) Spontaneous succession in central-European man-made habitats: what information can be used in restoration practice? Appl Veg Sci 6:125-129. https://doi.org/10.1111/j.1654-109X.2003. tb00572.x

Prévosto B, Kuiters L, Bernhardt-Römermann M, Dölle M, Schmidt W, Hoffmann M, Uytvanck JV, Bohner A, Kreiner D, Stadler J, Klotz S, Brandl R (2011) Impacts of land abandonment on vegetation: successional pathways in European habitats. Folia Geobot 46:303-325. https://doi.org/10.1007/s12224-010-9096-z

Robinson SA, King DH, Bramley-Alves J et al (2018) Rapid change in East Antarctic terrestrial vegetation in response to regional drying. Nat Clim Chang 8:879-884

Staniaszek-Kik M, Chmura D, Żarnowiec J (2019) What factors influence colonization of lichens, liverworts, mosses and vascular plants on snags? Biologia 74(4)

Storkey J, Meyer S, Still KS, Leuschner C (2012) The impact of agricultural intensification and land use change on the European arable flora. Proc R Soc B Biol Sci 279:1421-1429

Swacha G, Botta-Dukát Z, Kącki Z, Pruchniewicz D, Żołnierz L (2018) The effect of abandonment on vegetation composition and soil properties in Molinion meadows (SW Poland). PLoS One 13(5): e0197363. https://doi.org/10.1371/journal.pone.0197363

Timmermann A, Damgaard C, Strandberg MT, Svenning J (2015) Pervasive early 21 st-century vegetation changes across Danish semi-natural ecosystems: more losers than winners and a shift towards competitive, tall-growing species. J Appl Ecol 52(1):21-30. https://doi.org/10.1111/1365-2664.12374

Turner J, Colwell SR, Marshall GJ et al (2005) Antarctic climate change during the last 50 years. Int J Climatol 25(3):279-294. https://doi. org/10.1002/joc. 1130

Vondrák J, Kubásek J (2019) Epiphytic and epixylic lichens in forests of the Šmava mountains in the Czech Republic; abundance and frequency assessments. Biologia. https://doi.org/10.2478/s11756-01900207-0

Węgrzyn MH, Wietrzyk-Pełka P, Nicia P, Lehmann-Konera S, Olech M (2018) Short-term monitoring of Arctic trace metal contamination based on Cetrariella delisei bioindicator in Savlbard. Acta Soc Bot Pol 87(4):3600. https://doi.org/10.5586/asbp.3600

Publisher's note Springer Nature remains neutral with regard to jurisdictional claims in published maps and institutional affiliations. 